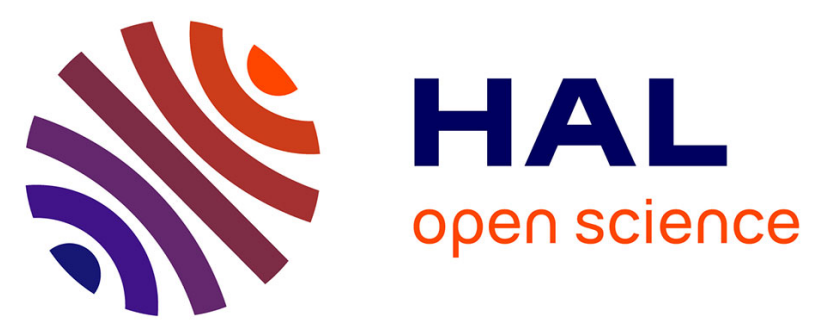

\title{
Combining laser diffraction, flow cytometry and optical microscopy to characterize a nanophytoplankton bloom in the Northwestern Mediterranean
}

R. Leroux, Gérald Grégori, F Carlotti, Karine Leblanc, Melilotus Thyssen, Mathilde Dugenne, Mireille Pujo-Pay, P. Conan, M.-P. Jouandet, Nagib

Bhairy, et al.

\section{To cite this version:}

R. Leroux, Gérald Grégori, F Carlotti, Karine Leblanc, Melilotus Thyssen, et al.. Combining laser diffraction, flow cytometry and optical microscopy to characterize a nanophytoplankton bloom in the Northwestern Mediterranean. Progress in Oceanography, 2018, 163, pp.248-259. 10.1016/j.pocean.2017.10.010 . hal-01638096

\section{HAL Id: hal-01638096 https://hal.science/hal-01638096}

Submitted on 20 Feb 2019

HAL is a multi-disciplinary open access archive for the deposit and dissemination of scientific research documents, whether they are published or not. The documents may come from teaching and research institutions in France or abroad, or from public or private research centers.
L'archive ouverte pluridisciplinaire HAL, est destinée au dépôt et à la diffusion de documents scientifiques de niveau recherche, publiés ou non, émanant des établissements d'enseignement et de recherche français ou étrangers, des laboratoires publics ou privés. 


\title{
Combining laser diffraction, flow cytometry and optical microscopy to characterize a nanophytoplankton bloom in the Northwestern Mediterranean
}

\author{
R. Leroux ${ }^{\mathrm{a}}$, G. Gregori ${ }^{\mathrm{a}}$, K. Leblanc ${ }^{\mathrm{a}}$, F. Carlotti ${ }^{\mathrm{a}}$, M. Thyssen ${ }^{\mathrm{a}}$, M. Dugenne ${ }^{\mathrm{a}}$, M. Pujo-Pay ${ }^{\mathrm{b}}$, \\ P. Conan ${ }^{\mathrm{b}}$, M.-P. Jouandet ${ }^{\mathrm{a}}$, N. Bhairy ${ }^{\mathrm{a}}$, L. Berline ${ }^{\mathrm{a}, *}$ \\ a Aix-Marseille Université, CNRS/INSU, Université Toulon, IRD, Mediterranean Institute of Oceanography, UM110, 163 Avenue de Luminy, 13288 Marseille, France \\ b Sorbonne Universités, UPMC Université Paris 06, UMR7621, Laboratoire d'Océanographie Microbienne, Observatoire Océanologique, F-66650 Banyuls/mer, France
}

\section{A R T I C L E I N F O}

\section{Keywords:}

Phytoplankton

Particles

LISST

Flow cytometry

Optical microscopy

POC

Mediterranean Sea

\begin{abstract}
A B S T R A C T
The study of particle size distribution (PSD) gives insights on the dynamics of distinct pools of particles in the ocean, which reflect the functioning of the marine ecosystem and the efficiency of the carbon pump. In this study, we combined continuous particle size estimations and discrete measurements focused on phytoplankton to describe a spring bloom in the North West Mediterranean Sea. During April 2013, about 90 continuous profiles of PSD quantified through in situ laser diffraction and transmissiometry (the Laser in situ Scattering and Transmissiometry Deep (LISST-Deep), Sequoia Sc) were complemented by Niskin bottle samples for flow cytometry analyses, taxonomic identification by optical microscopy and pigments quantification. In the euphotic zone, the PSD shape seen by the LISST was fairly stable with two particle volume peaks covering the $2-11 \mu \mathrm{m}$ and $15-109 \mu \mathrm{m}$ size fractions. The first pool strongly co-varied with the chlorophyll fluorescence emitted by phytoplankton cells. In addition, over the 2-11 $\mu \mathrm{m}$ fraction, the LISST derived abundance was highly correlated with the abundance of nanophytoplankton counted by flow cytometry. Microscopy identified a phytoplankton community dominated by nanodiatoms and nanoflagellates. High correlation of LISST derived particle carbon and Particulate Organic Carbon and high nitrogen in the Particulate Organic Matter also supported a dominance of actively growing phytoplankton cells in this pool. The second, broader pool of particles covering sizes $15-109 \mu \mathrm{m}$ was possibly microflocs coming from rivers and/or sediments. This study demonstrates the complementarity of continuous measurements of PSD combined with discrete measurements to better quantify size, abundance, biomass, and spatial (both vertical and horizontal) distribution of phytoplankton in open ocean environments.
\end{abstract}

\section{Introduction}

Plankton is a key compartment of marine ecosystems. The relation between plankton sizes and their rates of growth or sinking, referred to as allometry, is widespread (Peters, 1983). Sampling the size distribution of plankton in situ offers strong clues about the biomass stocks and fluxes that may transit between the various planktonic compartments. The size distribution is complementary to the species composition, with the advantage of being easier to measure. However, no single device can sample the whole size spectrum of organisms which covers several orders of magnitude. Any given device can only measure a specific size range with at a specific resolution given its construction and the rarity of large particles for a given volume sampled. Therefore, several devices must be used simultaneously in order to observe each part of the size spectrum. For instance, mesozooplankton organisms $(200-2000 \mu \mathrm{m})$ can be quantified by the Laser Optical plankton counter (LOPC, Herman et al., 2004; Espinasse et al., 2014). Nano to micro organisms $(1.25-200 \mu \mathrm{m})$ can be characterized using the LISST (Laser in situ Scattering and Transmissiometry), an instrument based on laser diffraction recently used to study living particles (Karp-Boss et al., 2007). For the ultraplankton (1-10 $\mu \mathrm{m}$, Strickland, 1965), flow cytometry has been used very successfully for the last 30 years (Yentsch et al., 1983).

In controlled conditions, the LISST allowed for the sizing and distinguishing of phytoplankton cells of contrasting shapes, provided they were approximately spherical (Karp-Boss et al., 2007; Rienecker et al., 2008; Font-Muñoz et al., 2015). In coastal areas, LISST estimates of particle volume and abundance compared well with particulate organic matter and chlorophyll $a$ (Chl-a) measurements (Serra et al., 2001;

\footnotetext{
* Corresponding author at: Mediterranean Institute of Oceanography, Aix Marseille University, Bâtiment Oceanomed, Marseille 13009, France.

E-mail address: leo.berline@mio.osupytheas.fr (L. Berline).
} 
Anglès et al., 2008; Kostadinov et al., 2012). More recently, off Hawaii at Station ALOHA in open-ocean oligotrophic conditions (Barone et al., 2015; White et al., 2015) LISST particle abundances compared well with phytoplankton abundances from flow cytometry. However, to our knowledge, no large scale oceanographic campaign has ever combined LISST measurements with several single cell techniques such as flow cytometry and optical microscopy. In the Northwestern Mediterranean, we gathered a large set of LISST profiles acquired in parallel with discrete bottle samples in the context of the Deep Water formation EXperiment (DeWEX) cruise. The objectives of this study were to combine these methodologies to (i) describe the particle pools seen by the LISST over the region, (ii) to discriminate the phytoplanktonic part in light of discrete measurements performed by flow cytometry and microscopy, and (iii) to analyze their spatial distribution in relation with their environment. The information collected allows for an accurate characterization of the phytoplankton bloom.

\section{Materials and methods}

\subsection{The DeWEX cruise}

The dataset was acquired during the second cruise of the Deep Water formation EXperiment (DeWEX-2) (MERMEX French Program; Conan (2013) doi: 10.17600/13020030), onboard the R/V Le Suroît. Sampling was carried out from April 5th to April 24th 2013 and covered the Northwestern Mediterranean Sea basin (Fig. 1).

A total of 100 stations were distributed following a star-shaped path crossing the cyclonic circulation of the basin. At each station, a sensor measuring conductivity, temperature, and depth (CTD, SeaBirdElectronics' $911+$ technology) was deployed in the water column. The CTD was coupled to a rosette carrying $12 \mathrm{~L}$ Niskin bottles. Beam transmittance (WetLabs C-Star at $650 \mathrm{~nm}$ ) and chlorophyll fluorescence (Chelsea Aquatracka III) were measured. The CTD-rosette lowering speed was $1 \mathrm{~m} \mathrm{~s}^{-1}$. During the ascending profile bottles were closed with on average 5 bottles in the upper $100 \mathrm{~m}$. Particulate nitrogen (PON) and phosphorus (POP) were simultaneously analyzed according to the wet oxidation procedure of Pujo-Pay and Raimbault (1994). PON and POP were collected by filtration of about $500 \mathrm{~mL}$ of seawater onto precombusted $(24 \mathrm{~h}) 0.7 \mu \mathrm{m}$ pore size glass fiber filters (Whatman GF/F, 25mm), that were immediately oxidized (30 min at $120^{\circ} \mathrm{C}$ ) into a Teflon vial. Filters were dried in an oven and stored, in ashed glass vial and in a dessicator until analyses in the laboratory on a continuous flow analysis (AAIII HR). Particulate organic carbon (POC) was collected by filtration of about $3 \mathrm{~L}$ of seawater onto precombusted (24 h) $0.7 \mu \mathrm{m}$ pore size glass fiber filters (Whatman GF/F, $25 \mathrm{~mm}$ ) as recommended in Schöniger (1952) protocol. Filters were dried in an oven and stored in ashed glass vial and in a dessicator until analyses in the laboratory on a CHN Perkin Elmer 2400. Chlorophyll pigment concentrations were quantified by HPLC (High Performance Liquid Chromatography) following Vidussi et al. (1996), modified by Claustre et al. (2004). The fluorescence signal of the fluorometer was calibrated with Chl-a pigment concentrations from HPLC as described in Mayot et al. (2017). A LISST-Deep (Sequoia Scientific) was placed vertically on the side of the rosette. Optical windows of LISST were rinsed with MilliQ water and wiped carefully prior to each cast.

\subsection{LISST measurements}

The LISST-Deep instrument obtains in situ measurements of particle size distribution, optical transmittance, and the optical volume scattering function (VSF) at depths down to $3000 \mathrm{~m}$. In this study, it measured the light attenuation and scattering from a red light-emitting laser diode of $670 \mathrm{~nm}$ wavelength at a frequency of $1 \mathrm{~Hz}$. Using Mie Theory, the scattering signal was transformed into particle volume concentration (hereinafter VC) in $\mu \mathrm{LL}^{-1}$ within 32 size classes, covering the size range $1.25-250 \mu \mathrm{m}$ with log-based increments [Agrawal and Pottsmith, 2000]. Note that we refer to the class boundaries in the text, while in the figures we use the center of classes. Following the conclusions of White et al. (2015), the kernel matrix corresponding to spherical particles was used to invert scattering into VC. The LISST measures all particles, independently of their nature (biogenic or not). A background scattering measurement is necessary to compute particle volume from the measured signal. Here, following Barone et al. (2015), we took the in situ minimum raw scattering signal for each profile in the 200-1000 m layer, to avoid the thick bottom nepheloid layers (Durrieu de Madron et al., 2017).

\subsubsection{Quality check of LISST data}

The pressure sensor of the LISST had a spurious offset so we used the CTD pressure sensor to correct LISST profile depths. First the deepest measurement of the LISST was offset to correspond to the deepest CTD measurement. Then, each LISST profile (total VC) was plotted together with synchronous measurements of fluorescence and/or transmittance. For 22 profiles showing profile mismatch (detected as an offset of a vertical gradient or a peak greater than $2 \mathrm{~m}$, see Fig. 2) a manual offset was applied to make the LISST profile match fluorescence and/or transmittance ones. Measurements were retrieved from the downward casts only. To avoid contamination by particles smaller and larger than the range covered by the LISST and ambient light contamination, data from the 1st and 32nd size classes were ignored (Andrews et al., 2011). Because of the high VC and high variability at classes 31 and 32 (from 180 to $250 \mu \mathrm{m}$ ) potentially impacting neighboring bins (Agrawal and Pottsmith, 2000), we discarded classes 29-32 from our analysis, restricting our analysis to classes below $128.9 \mu \mathrm{m}$ (i.e. 27 classes from 2nd to 28th).

Then, for each profile, a quality control procedure was applied: (I) LISST measurements with a VC larger than $1 \mu \mathrm{LL}^{-1}$ in any class were considered as outliers and removed. $1 \mu \mathrm{LL}^{-1}$ is an upper bound for surface volume concentration, considering this and other dataset collected in the same region. LISST measurements corresponding to layers with Brunt-Väisälä frequency $\mathrm{N}$ exceeding $0.025 \mathrm{~s}^{-1}$ were also removed to avoid "shlieren" (Mikkelsen et al., 2008) (0.04\% of measurements). (II) Following Barone et al. (2015), measurements were removed $(2.1 \%$ of measurements) whenever they fell outside of the mean \pm 3 standard deviation of a $10 \mathrm{~m}$ centered bin (containing 10 LISST measurements on average). (III) A median filter with a window size of one meter was applied. There was generally one measurement per meter but near the surface it could increase up to ten per meter. Then (IV) data were vertically interpolated on a one-meter resolution grid to fill the gaps. As transmittance was greater than $76 \%$ across all profiles, multiple scattering by particles was always negligible (Agrawal and Pottsmith, 2000). For three stations, wind speed exceeded $11 \mathrm{~m} \mathrm{~s}^{-1}$ and may have induced bubbles impacting LISST scattering signal near the surface (Barone et al., 2015). However, no visible effects on PSD were detected.

\subsubsection{LISST derived parameters}

For a given size class $i$, the abundance of particles ( $N i$; particles $\mathrm{L}^{-1}$ ) was calculated by dividing the $\mathrm{VC}_{i}$ measured by the spherical volume $\left(V_{i} ; \mu \mathrm{L}\right)$ of a sphere of diameter equal to this class center.

$\mathrm{Ni}=\mathrm{VC}_{\mathrm{i}} / \mathrm{V}_{\mathrm{i}}$

From the PSD, the median particle diameter was computed for all size classes (D50t) and for classes corresponding to the nanophytoplankton size range $(2-20 \mu \mathrm{m}$, D50nano). For particles in the size range $2-109 \mu \mathrm{m}$, the carbon content $\left(\mathrm{Bi} ; \mu \mathrm{mol} \mathrm{C} \mathrm{dm}^{-3}\right)$ was estimated according to Menden-Deuer \& Lessard's (2000) equation:

$B_{i}=10^{-0.583} \times V_{i}^{0.860} \times 8.3 \cdot 10^{-08} \times N_{i}$

with $V_{i}$ in $\mu \mathrm{m}^{3}$. Constant values in the equation were chosen to correspond to a phytoplankton community essentially composed by autotrophic protists including diatoms whose volume is smaller than 3000 


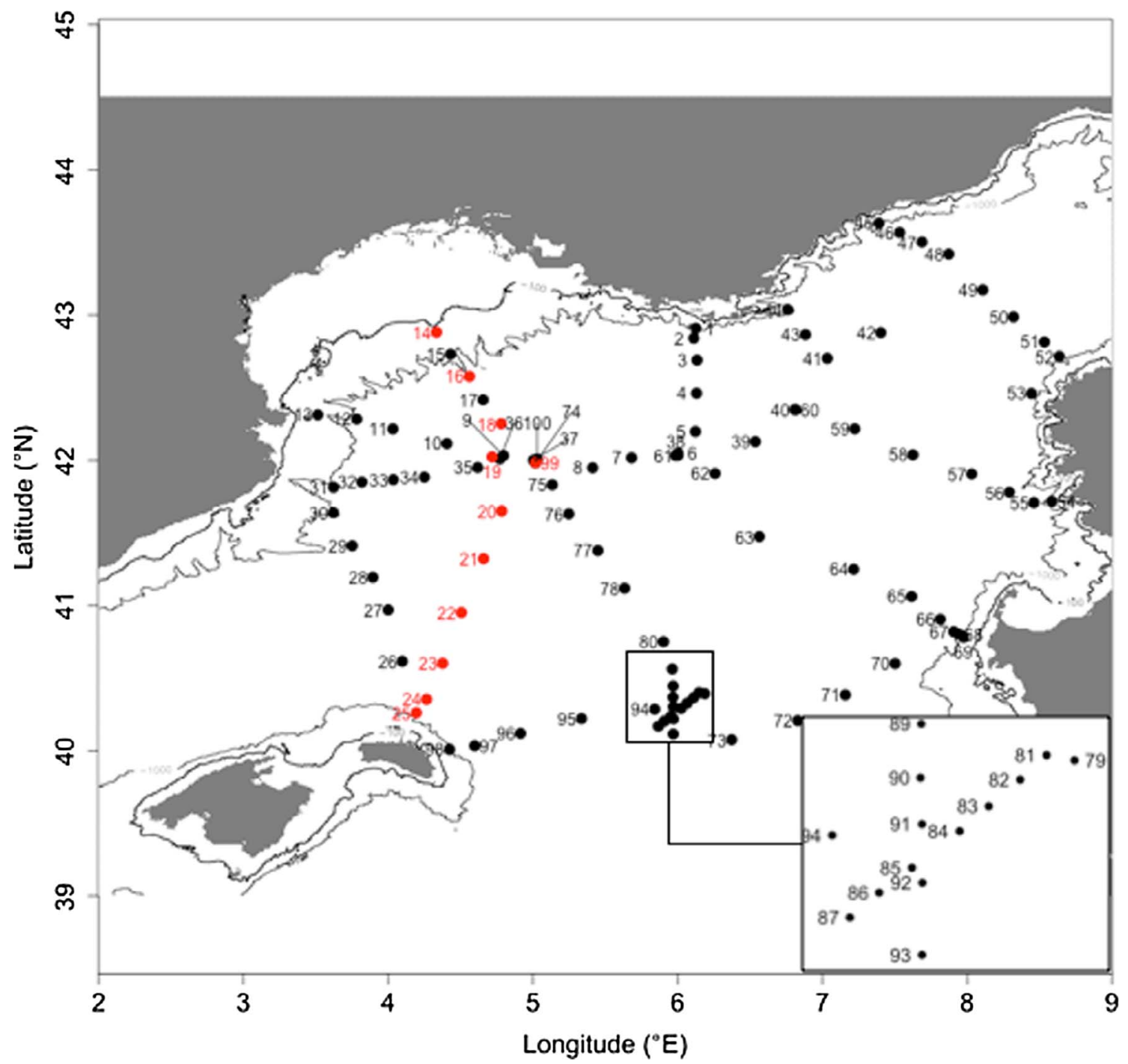

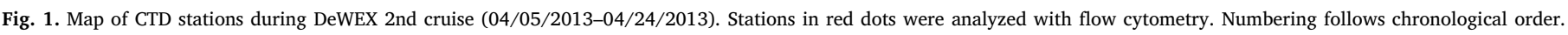
Isobaths $100 \mathrm{~m}$ and $1000 \mathrm{~m}$ are traced.

$\mu \mathrm{m}^{3}$ according to microscopic observations. For consistency, we chose to keep the same equation to estimate the carbon content of particles of volume greater than $3000 \mu \mathrm{m}^{3}$ (ESD $\left.>18 \mu \mathrm{m}\right)$.

\subsection{Flow cytometry measurements}

The abundances and size classes of phytoplankton were analyzed using traditional bench top flow cytometry. Samples were first collected in a $40 \mathrm{~mL}$ bottle from which $4 \mathrm{~mL}$ vials containing $0.02 \%$ final concentration glutaraldehyde were filled and incubated for $15 \mathrm{~min}$ in the dark. Samples were then frozen at $-80^{\circ} \mathrm{C}$ until analysis.

For each sample, $500 \mu \mathrm{L}$ of the working subsample $(950 \mu \mathrm{L}$ of the sample $+50 \mu \mathrm{L}$ of a Trucount $^{\circledast}$ beads solution $+10 \mu \mathrm{L}$ of a $2 \mu \mathrm{m}$ diameter beads solution) was analyzed by an Accuri $^{\mathrm{TM}}$ C6 (BD Biosciences) flow cytometer. Accuri ${ }^{\mathrm{TM}} \mathrm{C} 6$ was equipped with a $488 \mathrm{~nm}$ laser beam and a $640 \mathrm{~nm}$ laser beam. It measured green fluorescence (FL1; 533/30 nm), orange fluorescence (FL2; 585/40 nm) and Red fluorescence (FL3 $>650 \mathrm{~nm}$ ) induced by the blue $(488 \mathrm{~nm}$ ) laser beam; and a far red fluorescence (FL4 675/25 nm) induced by the red (640 $\mathrm{nm})$ laser beam. It also recorded Forward $\left(0^{\circ}, \pm 13^{\circ}\right)$ and Side $\left(90^{\circ}, \pm 13^{\circ}\right)$ Light Scatter intensities. Enumeration and mean optical properties were extracted using the AccuriCFlow Sampler (BD Biosciences) software. The concentration of Trucount ${ }^{\circledR}$ beads solution was used to verify flow stability. The use of $2 \mu \mathrm{m}$ beads helped defining the forward scatter threshold separating pico- (size $<2 \mu \mathrm{m}$ ) and nanophytoplankton $(2-20 \mu \mathrm{m})$ on 2D projections (cytograms). Cytometry only counted fluorescent particles as measurements were triggered by autofluorescence.

Eight cytograms were used to define areas corresponding to statistical phytoplankton populations, according to their own characteristics (size, fluorescence) as described in the literature (Veldhuis and Kraay, 2000; Grégori et al., 2001). In the following, this dataset is referred to as traditional flow cytometry.

An independent dataset was acquired during the cruise with an automated flow cytometer (Cytosense benchtop flow cytometer from CytoBuoy b.v) installed on a dedicated continuous sampling system set up to pump surface water (at $3 \mathrm{~m}$ depth, Dugenne et al., 2014). The Cytosense automated flow cytometer was equipped with a $488 \mathrm{~nm}$ laser beam. The volume analyzed was controlled by a calibrated peristaltic pump and each particle passed in front of the laser beam at a speed of 2 $\mathrm{m} \mathrm{s}^{-1}$. The particle resolved size range varied from $<1 \mu \mathrm{m}$ up to 800 $\mu \mathrm{m}$ in width and several hundreds of $\mu \mathrm{m}$ in length for chain forming cells. The trigger to record a signal was based on pigment fluorescence. The instrument allowed for the quantification of pico-, and nanophytoplankton populations, up to microphytoplankton when abundant enough in the $5 \mathrm{~mL}$ analyzed. Each phytoplankton group was manually 


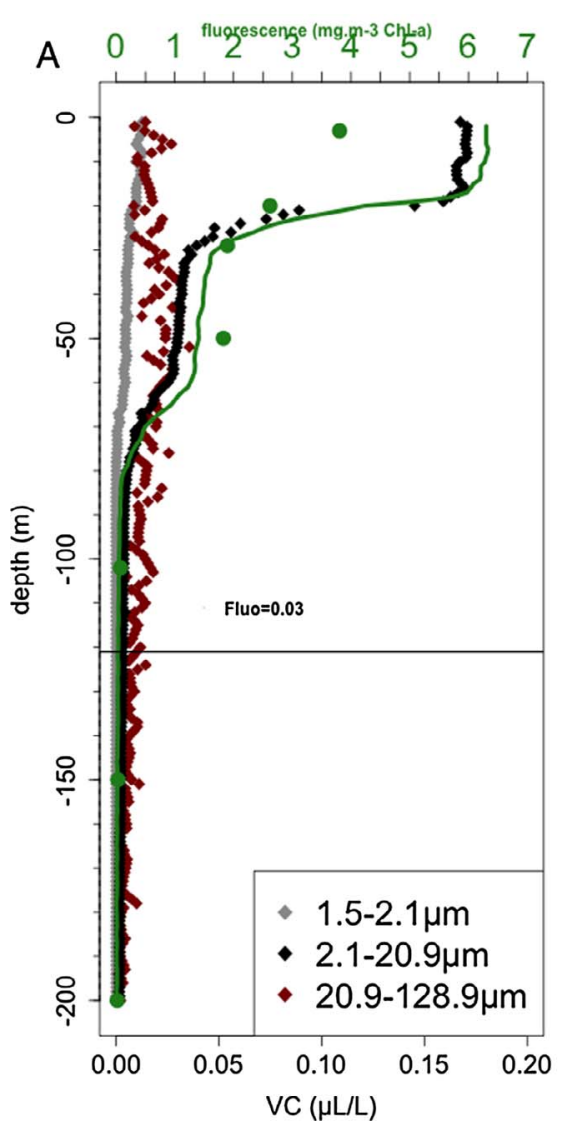

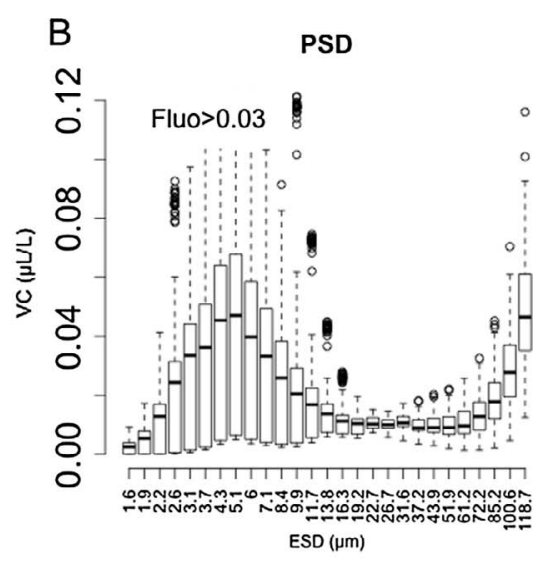

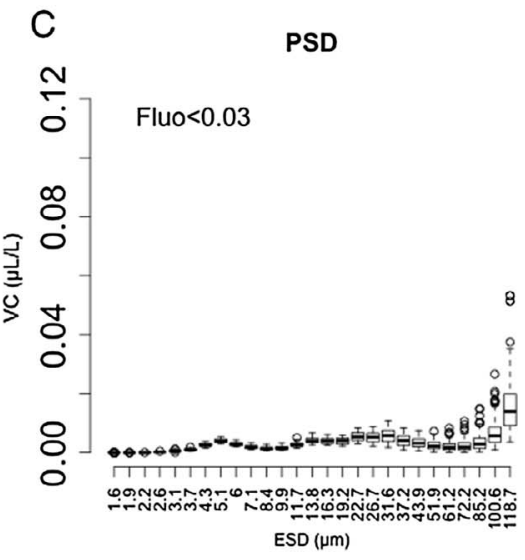

Fig. 2. Station 99. (A) Vertical profile of VC for pico $>1.5 \mu \mathrm{m}$, nano and micro size classes from the LISST (respectively gray, black and dark red dots), calibrated fluorescence and Chl-a concentration from bottles (respectively green line and dots). (B) PSD for layer above $Z_{\text {fluo }=0.03}$ and $C$ ) for layer below $Z_{\text {fluo }=0.03}$. ESD marks represent class centers. (For interpretation of the references to colour in this figure legend, the reader is referred to the web version of this article.)
Table 1

Census of stations and discrete measurements $(n=)$ available for comparison in our dataset.

\begin{tabular}{lllll}
\hline & CTD-fluo & LISST & Microscopy & Flow cytometry \\
\hline CTD-fluo & 100 & & & \\
LISST & 87 & 87 & & \\
Microscopy & 32 & 25 & 32 & $11(\mathrm{n}=108)$ \\
Flow cytometry & $11(\mathrm{n}=108)$ & $11(\mathrm{n}=108)$ & 4 & \\
\hline
\end{tabular}

clustered thanks to the Cytoclus ${ }^{\circledast}$ (http://www.cytobuoy.com/ products/software/) dedicated software. The high spatial resolution of the dataset for surface water and the large volumes analyzed strengthened the validation of nano-microphytoplankton counts that could be at the counting detection level limit for traditional flow cytometry (Thyssen et al., 2014). In the following, this dataset is referred to as continuous flow cytometry.

The upper size limit of objects that can be accurately analyzed is set by the tubing diameter, which is $100 \mu \mathrm{m}$ for traditional and $800 \mu \mathrm{m}$ for continuous cytometry. Then, the effective upper size limit is smaller, due to the rarity of large sized particles, sedimentation and sample fixation. It is worth noting that cytometers do not measure size directly but record forward scatter (FWS). The size estimates are based on the FWS intensity, calibrated with silica beads of known sizes. The relationship between size and FWS is used to estimate the phytoplankton size.

\subsection{Optical microscopy}

To reduce the workload, samples from only 32 stations of the DeWEX-2 cruise were analyzed by optical microscopy. Phytoplankton composition was determined for the surface Niskin bottles and some subsurface bottles. Samples of $125 \mathrm{~mL}$ were fixed with lugol after collection $(0.3 \%$ final concentration), stored in the dark and analyzed after sedimentation in Utermöhl settling chambers. Microorganisms were identified and when possible, counted and then divided into six categories: nanoplanktonic diatoms, microplanktonic diatoms, nanoflagellates, dinoflagellates, silicoflagellates and microzooplankton. Most nanoflagellates were autotrophs. Identification was possible for a size range of approximately 5-500 $\mu \mathrm{m}$. Furthermore, pictures of sedimented subsurface samples of 7 stations (13, 28, 31, 55, 71, 95 and 99) were taken and processed using a custom made ImageJ (Schneider et al., 2012) macro to extract the projected areas of each plankton cell. These areas were then converted to Equivalent Spherical Diameter (ESD) by computing diameter from a disk with an area equal to the projected area. Because of the limited number of stations, only the abundance of objects $<20 \mu \mathrm{m}$ was quantitatively estimated. Table 1 summarizes our dataset with its different data types.

\subsection{Data analysis}

To compare LISST measurements with measurements from Niskin bottles, LISST data were averaged over a $5 \mathrm{~m}$ range centered on the Niskin bottle depths. As our focus was on phytoplankton within the particulate pool, we used a criterion based on the calibrated fluorescence profile to select the uppermost layer with phytoplankton present within the particulate pool. This value $\left(>0.03 \mathrm{mg} \mathrm{m}^{-3} \mathrm{Chl}-\mathrm{a}\right)$ is the upper limit of the background level of fluorescence at depth well below the euphotic layer, and we define Zfluo $=0.03$ as its depth. For each profile, the mixed layer depth was computed using the density difference criterion of De Boyer Montegut et al. (2004).

\subsubsection{Chlorophyll fluorescence and VC from LISST}

To study the relation between VC and fluorescence, a table was built with all VC measurements at all stations at depth above Zfluo $=0.03$ (27 columns $\times 14930$ rows). A Principal Component Analysis (PCA) 
was computed on these data and fluorescence was added as a supplementary variable. Furthermore, Spearman correlations between fluorescence and VC for each LISST size class were computed. The significance threshold was reduced to 0.001 to take into account multiple testing.

\subsubsection{Traditional flow cytometry and abundance from LISST}

Flow cytometry was able to count phytoplankton cells from less than $1 \mu \mathrm{m}$ (Prochlorococcus and Synechococcus) to $100 \mu \mathrm{m}$ in size. To compare abundances derived by cytometry and by LISST, a robust overlap in the size range was needed. Thus, we retained the nanoplankton size range $(2-20 \mu \mathrm{m})$ for LISST measurements as a first guess, then adapted this range according to our results. 108 samples from bottles at stations 14, 16, 18-25 and 99 allowed comparison between LISST and cytometry measurements. Among these samples, 56 came from depths above Zfluo $=0.03$.

\subsubsection{Typology of profiles}

To identify patterns within our large dataset of VC profiles, we used a clustering algorithm. A table was built with each line corresponding to a station. Each line contained the sum VC for size $2.1-10.8 \mu \mathrm{m}$, averaged within the 0-70 m layer (as this layer contains the bulk of the phytoplankton biomass), as well as the surface VC over 2.1-10.8 $\mu \mathrm{m}$. Because of the lack of data between the surface and $10 \mathrm{~m}$ depth, 11 profiles were removed from the analysis. Missing surface VC measurements were filled by repeating the upper first measurements since the LISST PSD was fairly constant in the upper $10 \mathrm{~m}$ in most profiles. The Euclidean distance between each line of the table was computed and a clustering with PAM method (Partitioning Around Medoids, Reynolds et al., 1992) was applied. We retained 3 clusters following the criterion of Caliński and Harabasz (1974).

The data analysis was carried out using R (https://cran.r-project. $\operatorname{org} /$ ).

\section{Results}

\subsection{Environmental conditions during the cruise}

The sampling started during the peak of the phytoplankton spring bloom, about 10-15 days after the restratification started (Mayot et al., 2016). Mixed layer depths ranged from $581 \mathrm{~m}$ in the center of the sampling grid (former convection region) to $11 \mathrm{~m}$ in the peripheral area with a median of $23 \mathrm{~m}$. The Zfluo $=0.03$ varied from $73 \mathrm{~m}$ to $351 \mathrm{~m}$ with a median of $136 \mathrm{~m}$. Chlorophyll concentrations above Zfluo = 0.03 reached $6.34 \mathrm{mg} \mathrm{m}^{-3}$ with a median of $0.27 \mathrm{mg} \mathrm{m}^{-3}$.

\subsection{Pools of particles determined by the LISST volume concentration}

Station 99 illustrated a typical high VC profile (Fig. 2). The maximum Chl-a, here restricted to the upper $30 \mathrm{~m}$, had a vertical extent corresponding closely to the depth of maximum abundances for LISST size classes 2.1-20.9 $\mu \mathrm{m}$. The LISST upper size class $(20.9-128.9 \mu \mathrm{m})$ distribution was noisier and had several peaks in the 0-60 m layer. On the PSD, the upper layer with fluorescence $>0.03 \mathrm{mg} \mathrm{m}^{-3}$ showed a peak of VC for sizes 2.1-12.7 $\mu \mathrm{m}$ while this peak was strongly reduced at depth. A second, weaker peak at largest sizes classes was present at all depths but with higher particle volume at depths above Zfluo = 0.03 . These characteristics are shared by most stations except for the depth of maximum Chl-a.

The PCA of VC (Fig. 3) showed that almost all size classes strongly co-varied with axis 1 which represented $51 \%$ of the variance. Axis 2 represented $24 \%$ of the variance and separated two groups of classes: a first group containing classes $2.1-10.8 \mu \mathrm{m}$ with a negative correlation with axis 2 and a second group containing classes from 15.0 to 109.2 $\mu \mathrm{m}$ with a positive correlation. Classes $1.6,1.9$ and $118.7 \mu \mathrm{m}$ were excluded from the groups due to their low loads with dimension 1 .
These two groups were not correlated as illustrated by the angle $\sim 90^{\circ}$ between the two groups of vectors. The first group co-varied with fluorescence as shown by the PCA and Spearman correlations (rho always $>0.74, \mathrm{p}<10^{-3}$ ).

Based on the grouping of classes obtained by PCA, instead of using the definition of the 'nano' size range $2-20 \mu \mathrm{m}$, we used particles with a size range between $2.1 \mu \mathrm{m}$ and $10.8 \mu \mathrm{m}$ to compare with nanophytoplankton abundances determined by traditional flow cytometry. From now on, we will refer to the 2-11 $\mu \mathrm{m}$ Particle Pool and the 15-109 $\mu \mathrm{m}$ Particle Pool for simplicity. The 1 2-11 $\mu \mathrm{m}$ pool represented more than half of total VC and 79\% of total particles in terms of abundance. The $15-109 \mu \mathrm{m}$ pool represented $26 \%$ of total VC. Total VC $(1.5-128.9 \mu \mathrm{m})$ ranged from 0.09 to $1.27 \mu \mathrm{LL}^{-1}$ in the upper $70 \mathrm{~m}$ and decreased to about $0.04 \mu \mathrm{LL}^{-1}$ below $70 \mathrm{~m}$.

The Total Particle Volume was summed for sizes 1.25-109.2 $\mu \mathrm{m}$, including the first size class in order to compare our results with other studies (noted hereinafter $\mathrm{TPV}_{1,25-109}$ ). It was on average $0.35 \pm 0.18$ $\mu \mathrm{LL}^{-1}$ with a maximum of $0.86 \mu \mathrm{LL}^{-1}$ between 20 and $80 \mathrm{~m}$ depth. Below, at $125 \mathrm{~m}$ depth, $\mathrm{TPV}_{1,25-109}$ dropped to $0.094 \pm 0.082 \mu \mathrm{L} \mathrm{L}^{-1}$. Considering the two particle pools $2-11 \mu \mathrm{m}$ and $15-109 \mu \mathrm{m}$, on average $\mathrm{TPV}_{2-11}$ was $0.30 \pm 0.19 \mu \mathrm{LL}^{-1}$ above $70 \mathrm{~m}$, and $0.18 \pm 0.14 \mu \mathrm{LL}^{-1}$ for depths above $Z_{\text {fluo }=0.03}$. For particle pool 15-109 $\mu \mathrm{m}$, TPV $15-109$ was equal to $0.13 \pm 0.09 \mu \mathrm{LL}^{-1}$ within the upper $70 \mathrm{~m}$ layer, and $0.10 \pm 0.06 \mu \mathrm{LL}^{-1}$ for depths above $Z_{\text {fluo }}=0.03$. Below $Z_{\text {fluo }=0.03}$, $\mathrm{TPV}_{2-11}$ strongly decreased to $0.004 \pm 0.003 \mu \mathrm{LL}^{-1}$ and $\mathrm{TPV}_{15-109}$ dropped to $0.014 \pm 0.016 \mu \mathrm{LL}^{-1}$. These values did not take into account depths deeper than $1000 \mathrm{~m}$ to avoid the bottom nepheloid layer (Durrieu de Madron et al., 2017). Over the upper $150 \mathrm{~m}$, the median size $D 5 O_{t}$ was $54.1 \mu \mathrm{m}$ and $D 50_{\text {nano }}$ was $14.7 \mu \mathrm{m}$. When only the upper $70 \mathrm{~m}$ were considered, $D 50_{t}$ decreased to $15.9 \mu \mathrm{m}$ and $D 50_{\text {nano }}$ to 5.4 $\mu \mathrm{m}$.

\subsection{Estimation of the phytoplanktonic fraction within the 2-11 $\mu$ m particle pool}

For the nanophytoplankton size classes, there was a good correlation between particle abundances from LISST and nanophytoplankton abundances determined by traditional flow cytometry (Spearman rho $=0.92, \mathrm{p}<10^{-3}$ ). LISST abundances were most of the time higher than traditional flow cytometry. The scatter is also reduced for higher abundances.

The proportion between LISST and traditional flow cytometry abundance measurements was computed with the 56 samples above $\mathrm{Z}_{\text {fluo }}=0.03$. Regardless of fluorescence, the ratio LISST/traditional flow cytometry was greater than 1 (median $=2.82$ ).

Nanodiatoms and nanoflagellates were counted by optical microscopy and abundances were compared with the LISST 2-11 $\mu \mathrm{m}$ abundance (Fig. 5). For both nanodiatoms and nanoflagellates, the spearman correlation was significant (respectively rho $=0.49, \mathrm{p}=0.013$ and rho $=0.52, \mathrm{p}=0.008$ ). However, LISST abundances were much higher than total nanophytoplankton counts (median about 6.76 times more). This ratio was closer to 1 when abundances increased.

\subsection{Composition and size distribution of plankton cells}

Two main dominant groups were identified by optical microscopy: nanoplanktonic diatoms and diverse nanoflagellates (respectively $18 \%$ and $78 \%$ on average abundance over the 32 samples). They were the dominant groups except at stations 88 and 89 (South) where small dinoflagellates were more numerous. Diatoms were dominated everywhere by species Minidiscus trioculatus (on average 93\%) with a maximum abundance observed at station 84 with $19.10^{6}$ cells L $^{-1}$ and representing $88 \%$ of total plankton counted. This centric diatom species is cylindrical with diameter from 2 to $5 \mu \mathrm{m}$ (Throndsen et al., 2007). Nanoflagellates dominated the nanoplankton community in 20 out of 32 stations where they represent $90 \%$ of the total plankton counted by 
Variables factor map (PCA)

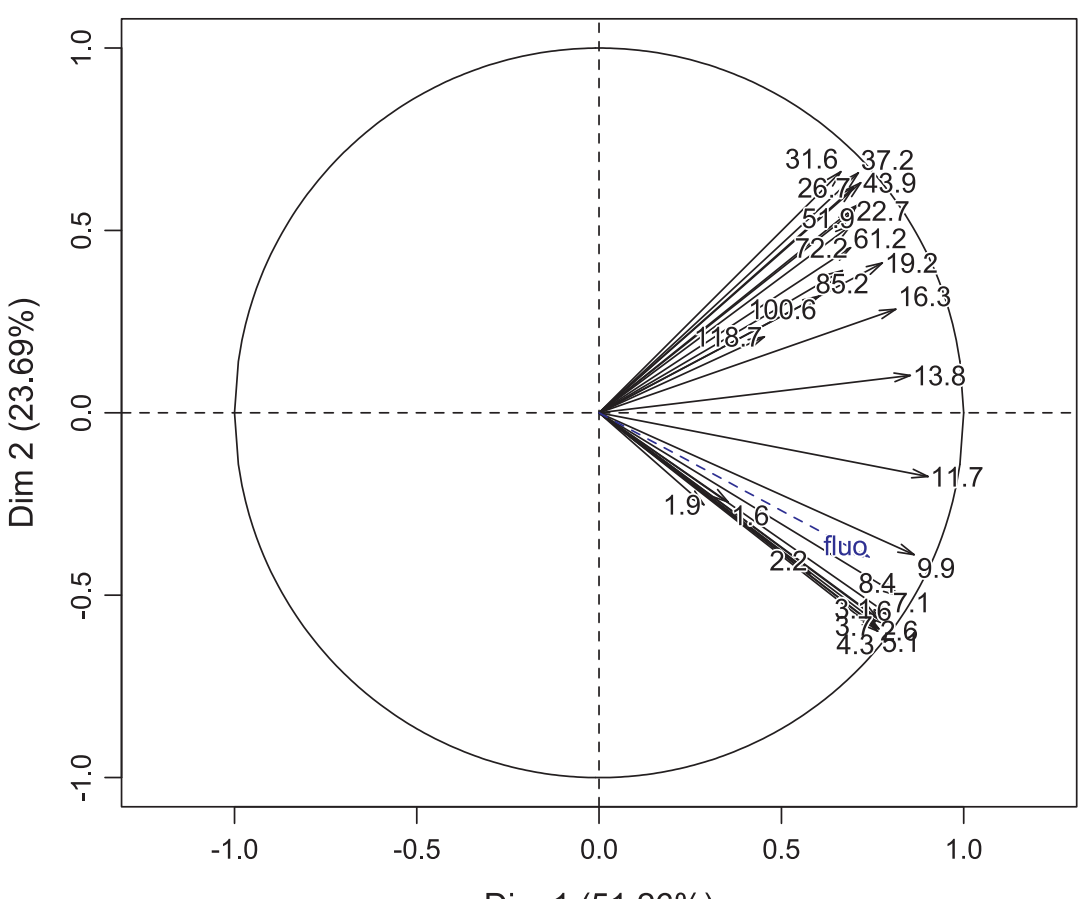

Fig. 3. PCA of VC table for size classes from 1.5 to $128.9 \mu \mathrm{m}$ combining all measurements (numbers refer to the class centers). Only measurements above $Z_{\text {fluo }=0.03}$ were considered. The dotted blue arrow represents the supplementary variable fluorescence. The first axis contains $51.26 \%$ of total variance and the second, 23.69\%. (For interpretation of the references to colour in this figure legend, the reader is referred to the web version of this article.)

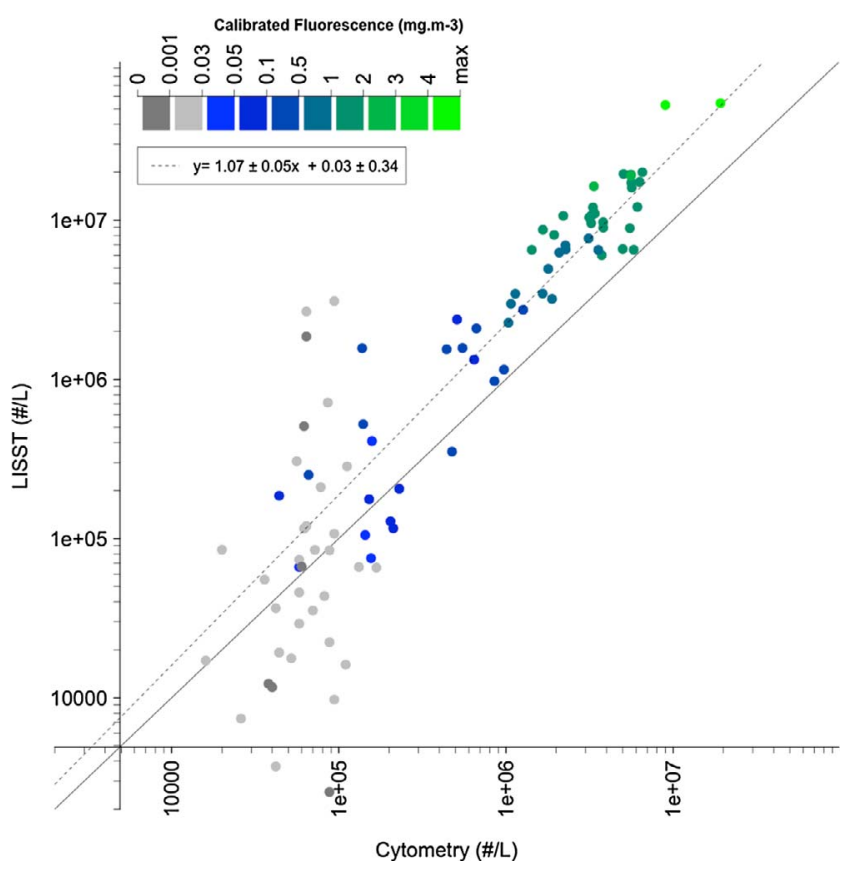

Fig. 4. Abundances from the LISST Particle Pool 2-11 $\mu \mathrm{m}$ versus abundance from traditional flow cytometry (nanophytoplankton) for 108 samples gathered at stations 14, 16, 18-25 and 99. In dotted line, the linear model with formula between those variables for samples at depth above $Z_{\text {fluo }}=0.03$. Solid line is equation $y=x$. Dots are colored from grey to blue then green according to their corresponding fluorescence. Axis are log scaled. The linear fit equation for non-transformed data is $y=3.05 \pm 0.2 \mathrm{x}-2.69 \cdot 10^{5} \pm 8.41 \cdot 10^{5}$. (For interpretation of the references to colour in this figure legend, the reader is referred to the web version of this article.)

optical microscopy. For many stations, this was the only taxon visible by optical microscopy. The maximum recorded concentration was $75 \cdot 10^{6}$ cells L $^{-1}$ at station 28.

The PSD determined from optical microscopy (ImageJ processing) and LISST measurements both showed a particle volume maximum for

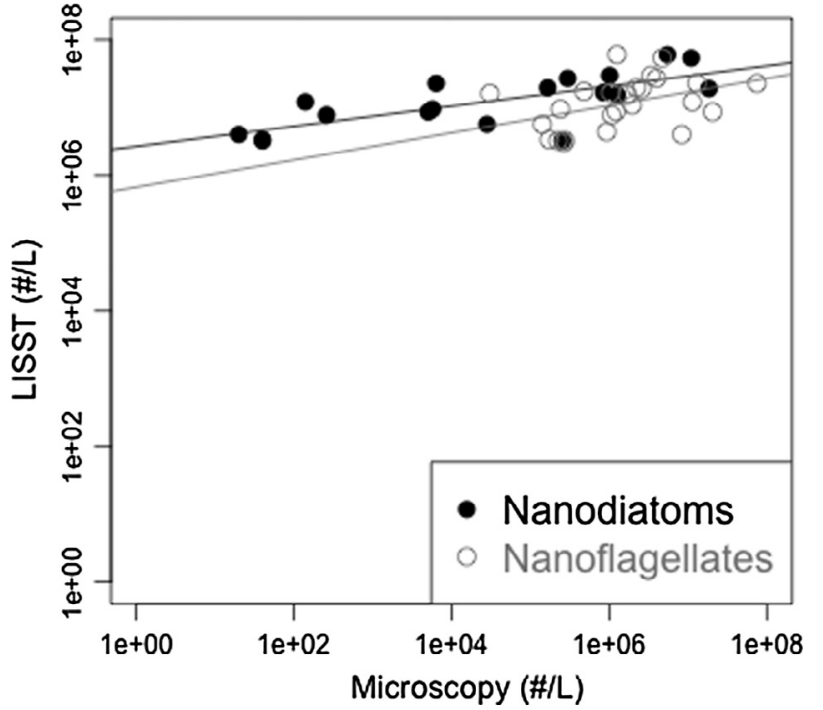

Fig. 5. Abundances from the Particle Pool 2-11 $\mu \mathrm{m} v s$ abundances of the most abundant categories counted by optical microscopy, nanodiatoms and nanoflagellates. Axis are log scaled. Lines represent linear models fitting with these data $(n=27)$.

sizes between 3 and $6 \mu \mathrm{m}$ (Fig. 6a). Median particle volume estimated from microscopy was smaller than that determined by the LISST (Fig. 6b).

\subsection{Contribution of the small and large particle pools to POC}

A good agreement between LISST derived particle carbon for Particle Pool 2-11 $\mu \mathrm{m}$ and POC was found (Fig. 7) at depths above $\mathrm{Z}_{\text {fluo }=0.03}$. The variation in LISST derived particle carbon was essentially driven by the $2-11 \mu \mathrm{m}$ Particle Pool. The LISST derived particle carbon of the 15-109 $\mu \mathrm{m}$ Particle Pool was not correlated with POC and was approximately constant throughout the water column (average 5.4 $\mathrm{mgC} \mathrm{m}^{-3}$ ). 

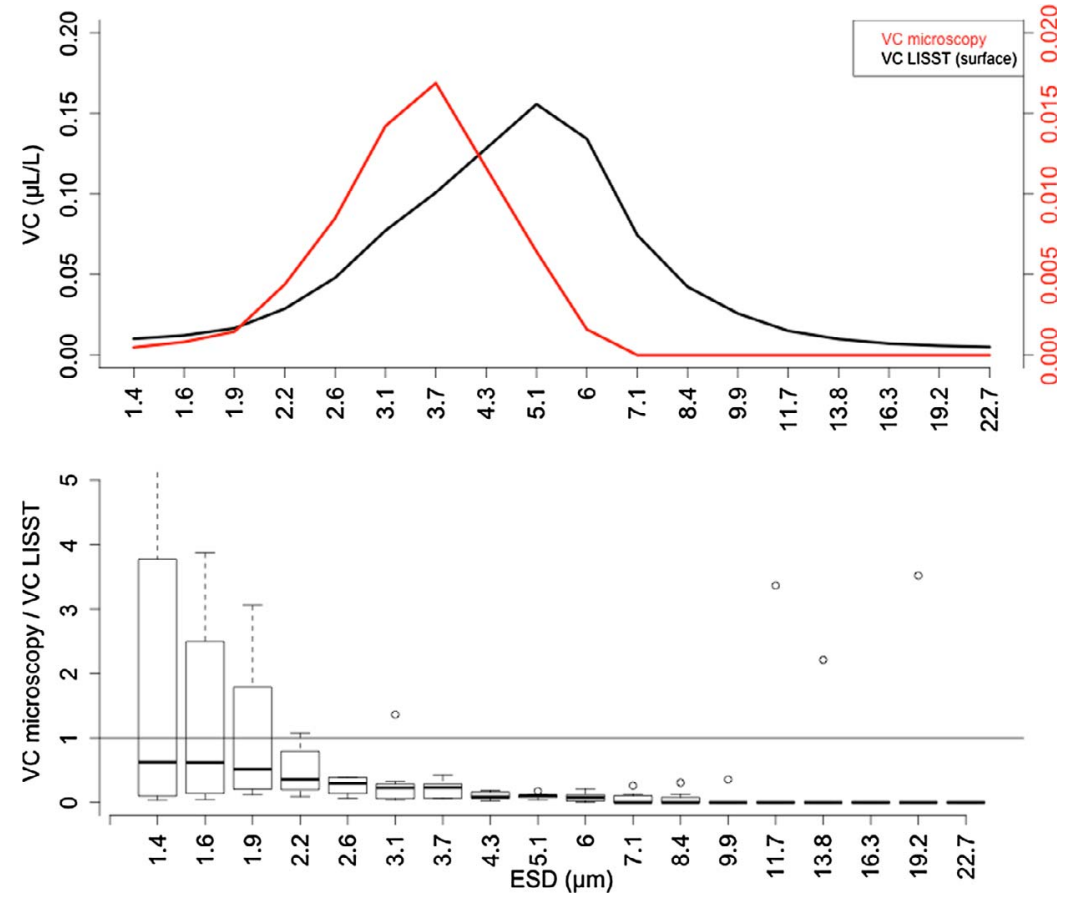

Fig. 6. (A) An example of PSD from optical microscopy and LISST at station 28 and (B) Boxplot of the ratio VC (microscopy)/VC (LISST) for the seven stations considered. ESD marks represent class centers.

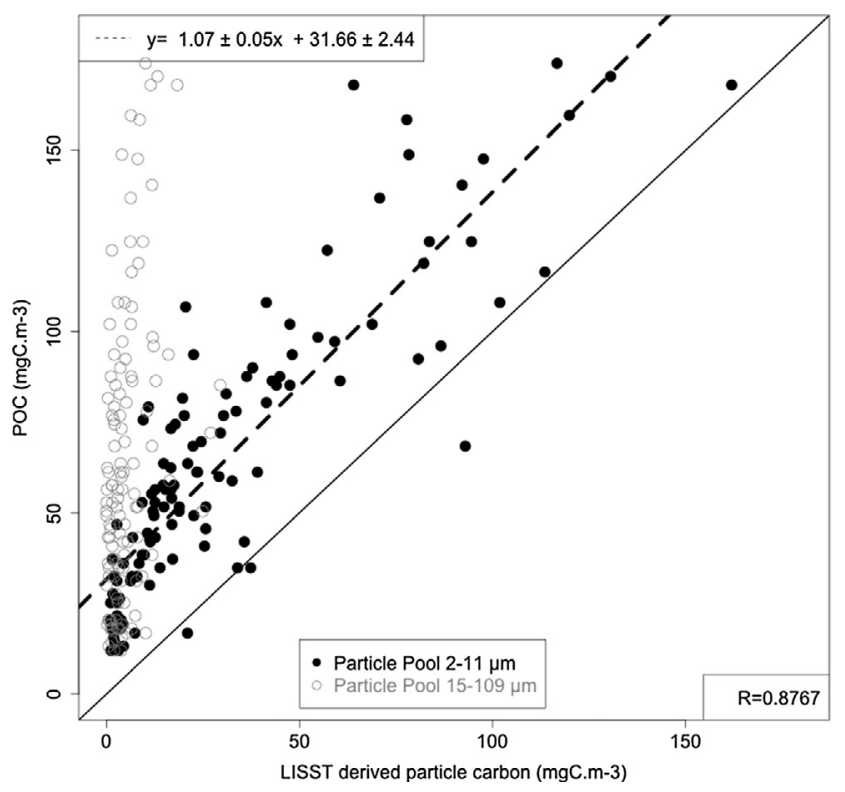

Fig. 7. POC vs LISST derived particle carbon. Solid line: line $y=x$. Dotted line: linear model for the Particle Pool 2-11 $\mu \mathrm{m}$. Spearman correlation test is significant p-value < 0.001 and $\mathrm{R}=0.8767$.

\subsection{Typology of profiles for the 2-11 $\mu$ m particle pool}

The three clusters identified with the PAM method illustrate the gradient of profiles with high VC concentrated in the first $30 \mathrm{~m}$ (red) to profiles with lower VC diluted from 0 to $80 \mathrm{~m}$ (blue) (Fig. 8a). The intermediate cluster had a shape similar to the blue cluster but with higher VC. The horizontal distribution of clusters (Fig. 8B) showed a center region with high VC surrounded by a peripheral region of mixed intermediate and low VC, both on the northern and southern sides of the center region. The spot of intermediate VC in the south corresponded to an anticyclonic eddy (Fig. $8 \mathrm{~b}$ and c).

\section{Discussion}

\subsection{Particle pools seen by the LISST: Comparison with other studies}

Two particle pools were identified with LISST PSD, in the range $2-11 \mu \mathrm{m}$ and $15-109 \mu \mathrm{m}$. These particle pools do not covary and their vertical distribution differ. We first review other studies reporting observations of particle pools by LISST.

In February, during a flood event of the Rhône river, Many et al. (2016) identified several pools of particles with a LISST-100 and LISSTHOLO over a meridional transect across the Gulf of Lions shelf. On the outer shelf, comparable to offshore waters sampled during DeWEX-2, three modes were identified on the PSD, centered around $10 \mu \mathrm{m}$ (3-30 $\mu \mathrm{m}), 100 \mu \mathrm{m}(30-200 \mu \mathrm{m})$ and $400 \mu \mathrm{m}$. The $10 \mu \mathrm{m}$ mode was attributed to fine silts, while the $100 \mu \mathrm{m}$ mode was identified as microflocs, themselves composed of fine grained particles from Rhone river. The potential contribution of phytoplankton to these pools was not quantified.

In the Cretean Sea (Eastern Mediterranean) Karageorgis et al. (2012) observed a PSD dominated by particles of size around 60-80 $\mu \mathrm{m}$ identified as microflocs. Spring TPV1,25-250 was generally 6-10 $\mu \mathrm{LL}^{-1}$ in $0-15 \mathrm{~m}$, and was $<1 \mu \mathrm{LL}^{-1}$ in deep water. Microflocs $<100$ $\mu \mathrm{m}$ dominated TPV with D50 between 82 and $92 \mu \mathrm{m}$. Aggregates were generally in the $60-80 \mu \mathrm{m}$ size range, some larger aggregates $(100 \mu \mathrm{m})$ were fecal pellets. Our particulate pool 15-109 $\mu \mathrm{m}$ probably corresponds to the pool covering sizes $30-200 \mu \mathrm{m}$ identified as microflocs by Many et al. (2016) over the outer Gulf of Lions and Karageorgis et al. (2012) in the Cretean Sea. Its particle volume is higher in the first $70 \mathrm{~m}$ but it is still present at depth below $70 \mathrm{~m}$ (Fig. 2), for some profiles down to $1000 \mathrm{~m}$ deep. This vertical distribution, extending far below the surface layer, suggests non-living particles in this pool (detritus, aggregates and/or terrigenous particles).

The $2-11 \mu \mathrm{m}$ pool detected here was not shown in Karageorgis et al. (2012). In contrast, Barone et al. (2015) reported a similar particle pool of size between 3 and $10 \mu \mathrm{m}$ in the oligotrophic Northern Pacific Subtropical gyre during summer. This pool dominated their VC ( $90 \%$ of $1.25-109.2 \mu \mathrm{m}$ for depths $20-180 \mathrm{~m}$ ) but no composition was available. The TPV1,25-109 of Barone et al. (2015) was $0.076 \pm 0.014 \mu \mathrm{LL}^{-1}$ for $20-80 \mathrm{~m}$ with a maximum of $0.16 \mu \mathrm{L} \mathrm{L}^{-1}$ close to the mixed layer 


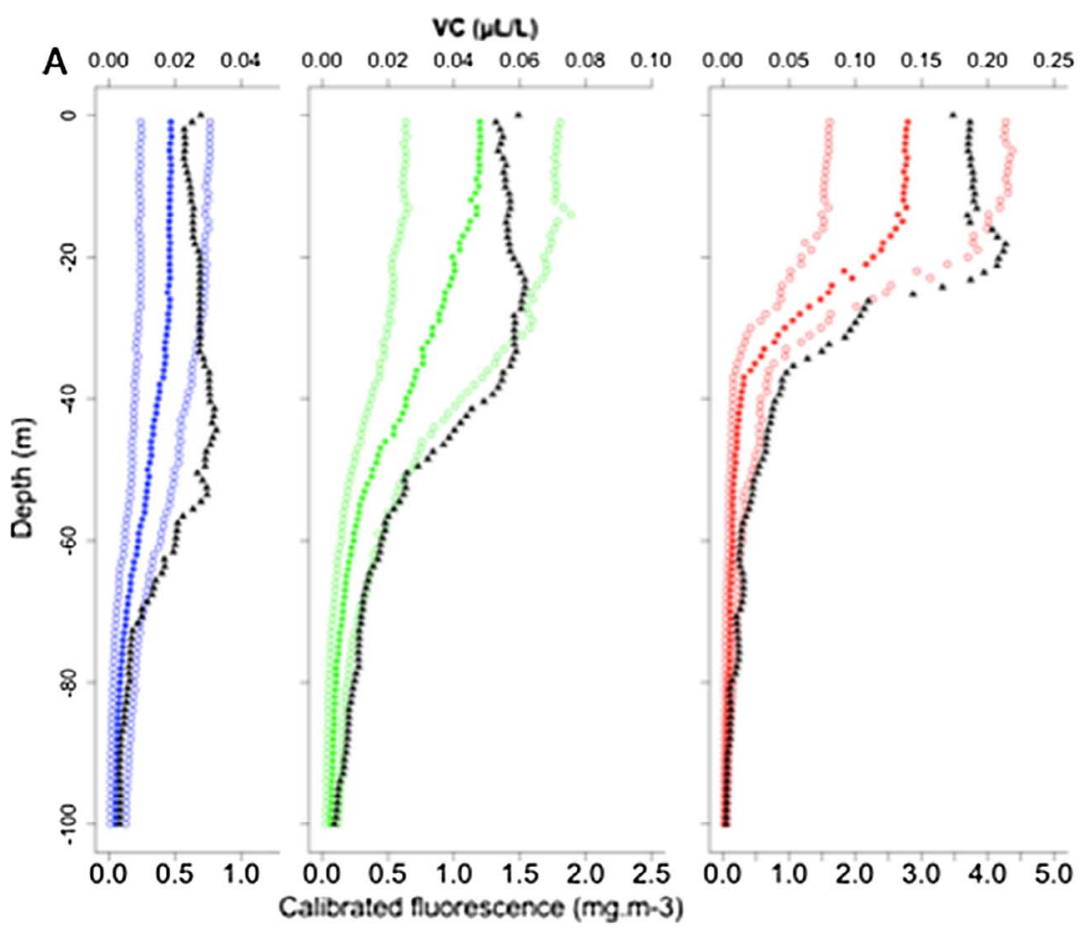

Fig. 8. Clusters of the VC over the Particle Pool 2-11 $\mu \mathrm{m}$ from the LISST. Only the first $70 \mathrm{~m}$ of profiles were used. (A) Vertical profiles of the quantiles 25, 50 and 75 of the total VC for each cluster (B) Horizontal distribution of the three clusters (C) Boxplot of the VC over the Particle Pool $2-11 \mu \mathrm{m}$ for each cluster.
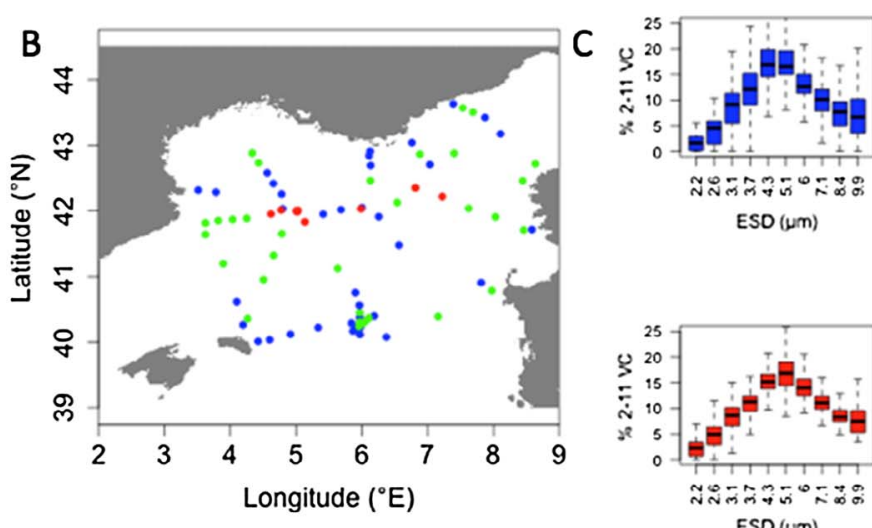

depth. In the same location but taking into account seasonal fluctuations, White et al. (2015) reported a TPV1,25-109 of $0.065 \pm 0.033$ $\mu \mathrm{LL}^{-1}$ at $25 \mathrm{~m}$ and $0.032 \pm 0.017 \mu \mathrm{LL}^{-1}$ at $125 \mathrm{~m}$. Our data showed about 10 times higher particle volume for the same depth range and season.

For Barone et al. (2015) and White et al. (2015), particles larger than $100 \mu \mathrm{m}$ were below detection and thus not quantified. Consequently, they observed a Davg of $10.7-11 \mu \mathrm{m}$ for $0-150 \mathrm{~m}$ and the $2-20$ $\mu \mathrm{m}$ fraction dominated TPV. In our study, Davg is about $12.4 \mu \mathrm{m}$ on average which confirms the dominance of the $2-11 \mu \mathrm{m}$ particle pool in the full particle pool. The $15-109 \mu \mathrm{m}$ particle pool made up of microflocs with probably sediment and/or riverine origin is thus peculiar to the Mediterranean basin. The location of Station ALOHA, remote from terrestrial influences and in the subtropical gyre, probably explains the absence of this pool.

\subsection{Nature of particles seen by LISST}

To better understand what is the type of the particles detected by the LISST, PSD data were compared with several discrete measurements. Table 2 summarizes the characteristics of each method.

LISST derived particle carbon and POC strongly co-varied (Fig. 7). Barone et al. (2015) also showed a strong co-variation of LISST derived

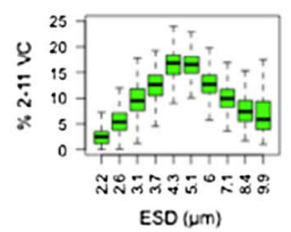

particle carbon and POC. Using VC from 1.25 to $109.2 \mu \mathrm{m}$, Barone et al. (2015) estimated that about 38\% (according to their Fig. 7) of total particulate carbon was contributed by LISST derived particle carbon between 25 and $75 \mathrm{~m}$ depth. In our study, LISST derived particle carbon for the same size range and the $10-75 \mathrm{~m}$ layer, represented on average 60\% (CI95\%: 0.53-0.67) of POC. Our figures are larger in magnitude and indicate the dominance of larger $(2-11 \mu \mathrm{m})$ particle sizes in the total POC than for Barone et al. (2015). Considering the high correlation obtained, LISST derived particle carbon can be used as a proxy for POC in our dataset.

Moreover, the linear model computed on these data for the 2-11 $\mu \mathrm{m}$ particle pool showed a very close relation between total POC and LISST derived particle carbon for this size class Indeed, coefficients are significant with a slope close to 1 (Fig. 7). This means that POC variations are mostly driven by the abundance of particles between 2.1 and 10.8 $\mu \mathrm{m}$. Additionally, the stoichiometry of the POM is peculiar (on average $42 \pm 38: 9 \pm 6: 1$ for $\mathrm{C}: \mathrm{N}: \mathrm{P}$ molar ratio above $Z_{\text {fluo }}=0.03$ ). The $\mathrm{C}: \mathrm{N}$ ratio (4.2 \pm 1.9$)$ is lower than Redfield ratio (6.6). This low C:N is typical of phytoplankton populations experiencing high growth rates (Goldman et al., 1979). This intense growth is also supported by high primary production estimates ranging from 85 to $9036 \mathrm{mgC} / \mathrm{m}^{2} / \mathrm{d}$ for the upper $50 \mathrm{~m}$ (median $1444 \mathrm{mgC} / \mathrm{m}^{2} / \mathrm{d}$, P Conan et al., unpublished data). Conversely, there is no correlation of POC with the 15-109 $\mu \mathrm{m}$ LISST 


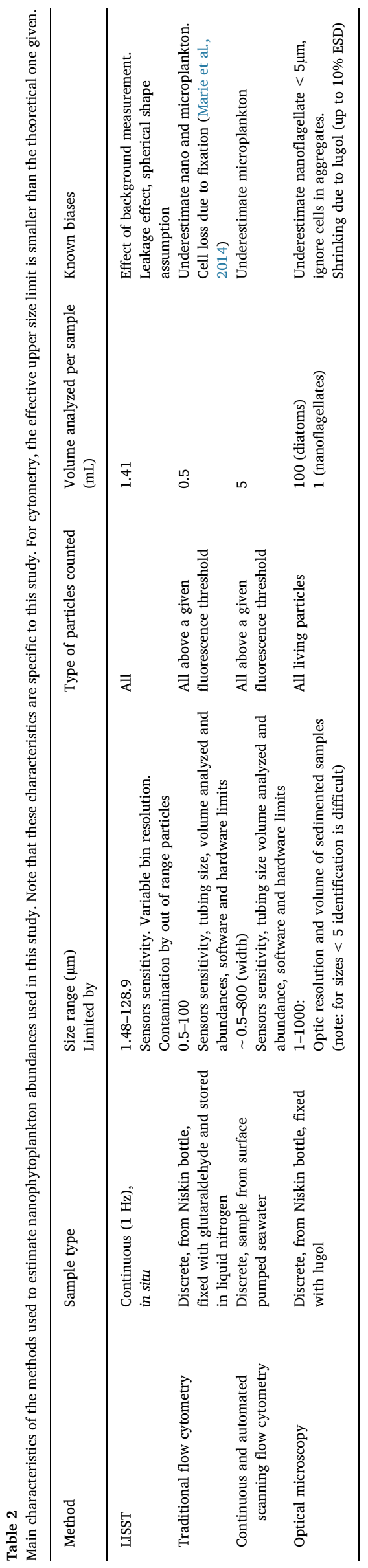

derived particle carbon suggesting an inorganic nature as in Karageorgis et al. (2012).

Compared to cytometry data, the $2-11 \mu \mathrm{m}$ LISST particle pool covaried strongly with nanophytoplankton counted by traditional flow cytometry (Fig. 4; rho $=0.92$ ). However, LISST abundances were about 3 times higher than those obtained by traditional flow cytometry. First, this higher abundance from LISST is expected as living, non-living and inorganic particles are all counted, while the flow cytometry count is triggered by fluorescence induced in pigments present in phytoplankton. Second, we suspect an underestimation by traditional flow cytometry. Underestimation by traditional flow cytometry is supported by the comparison of abundances obtained with continuous flow cytometry, which analyzes a larger volume $(5 \mathrm{~mL}$ instead of $0.5 \mathrm{~mL}$ ). Comparing measurements for the best-matching surface water samples (sampled at distance $<2.4 \mathrm{~km}$ ), traditional and continuous flow cytometry results were strongly correlated (Rho $=0.9, \mathrm{n}=9$ ), but continuous flow cytometry counted on average 2.90 times more particles within the nanophytoplankton group (IC95\%: 1.96-3.84) (data not shown). This underestimation was already observed (Thyssen et al., 2014) but its causes are not settled. Taking this underestimation of traditional flow cytometry into consideration, the abundance of the nanophytoplankton determined by flow cytometry is roughly equivalent to the LISST abundance for particle pool 2-11 $\mu \mathrm{m}$. Since both instruments gave similar results in particle counts, this suggests that the $2-11 \mu \mathrm{m}$ pool is dominated by nanophytoplankton and that the LISST can be used successfully to monitor it.

Compared to optical microscopy observations in the range 1-15 $\mu \mathrm{m}$, the average of particles detected by the LISST is larger than that estimated by microscopy (Fig. 6). This can be partly linked to the lugol fixation of samples (up to 10\% decrease in diameter, Montagnes et al., 1994) but the LISST also assumes particle sphericity which could influence its counting (Karp-Boss et al., 2007). The abundance estimated by optical microscopy is much smaller than the LISST abundance. Based on the good agreement between LISST and cytometry abundances (Fig. 4), we suspect an underestimation of abundance by optical microscopy for this size range, possibly linked to the non-counting of aggregates containing cells. In terms of phytoplanktonic composition, microscopy analysis showed a large nanophytoplanktonic abundance with dominance of nanoflagellates and actively growing nanodiatoms dominated by Minidiscus trioculatus (numerous dividing cells). The size range of these diatoms (diameter of $1-5 \mu \mathrm{m}$ when the cell is not in division) is consistent with the LISST $2-11 \mu \mathrm{m}$ peak.

The phytoplanktonic nature of the $2-11 \mu \mathrm{m}$ pool is also supported by its fluctuation with respect to the hour of the day. PSD were time averaged into $4 \mathrm{~h}$ time bins. In the $0-30 \mathrm{~m}$ layer, we found a significant increase of particle volume from the morning to the afternoon (resp. $0.34 \pm 0.22 \mu \mathrm{LL}^{-1}$ from 7 to 11 am and $0.62 \pm 0.48 \mu \mathrm{L} \mathrm{L}^{-1}$ from 3 to $11 \mathrm{pm}$, Kruskal-Wallis chi-squared $\left.=33.04, \mathrm{p}=3.7 \cdot 10^{-6}\right)$. Mean size also increased from the morning to the afternoon $(4.67-5.00 \mu \mathrm{m}$, Kruskal-Wallis chi-squared $=13.9, \mathrm{p}=.016$ ). This is consistent with phytoplankton cell cycle observations by cytometry in the Northwestern Mediterranean Sea (Dugenne et al., 2014; Thyssen et al., 2014). Daylight allows photosynthesis to occur, leading to an increase of cell size and total particle volume in the afternoon, while at night cells divide leading to smaller sizes in the morning (Vaulot and Chisholm, 1987).

\subsection{Spatial distribution of the 2-11 $\mu$ m particle pool}

The three clusters of LISST VC profiles for the $2-11 \mu \mathrm{m}$ particle pool illustrate three types of profiles, from low (blue), intermediate (green), to high (red) VC (Fig. 8). These three profile types are essentially distinguished by their integrated value of VC, and to a lesser extent by their shape. The increasing value of integrated VC from the blue to the red cluster is consistent with increasing POC, Chl-a and nanophytoplankton abundance values as shown in Fig. 9. To understand the 

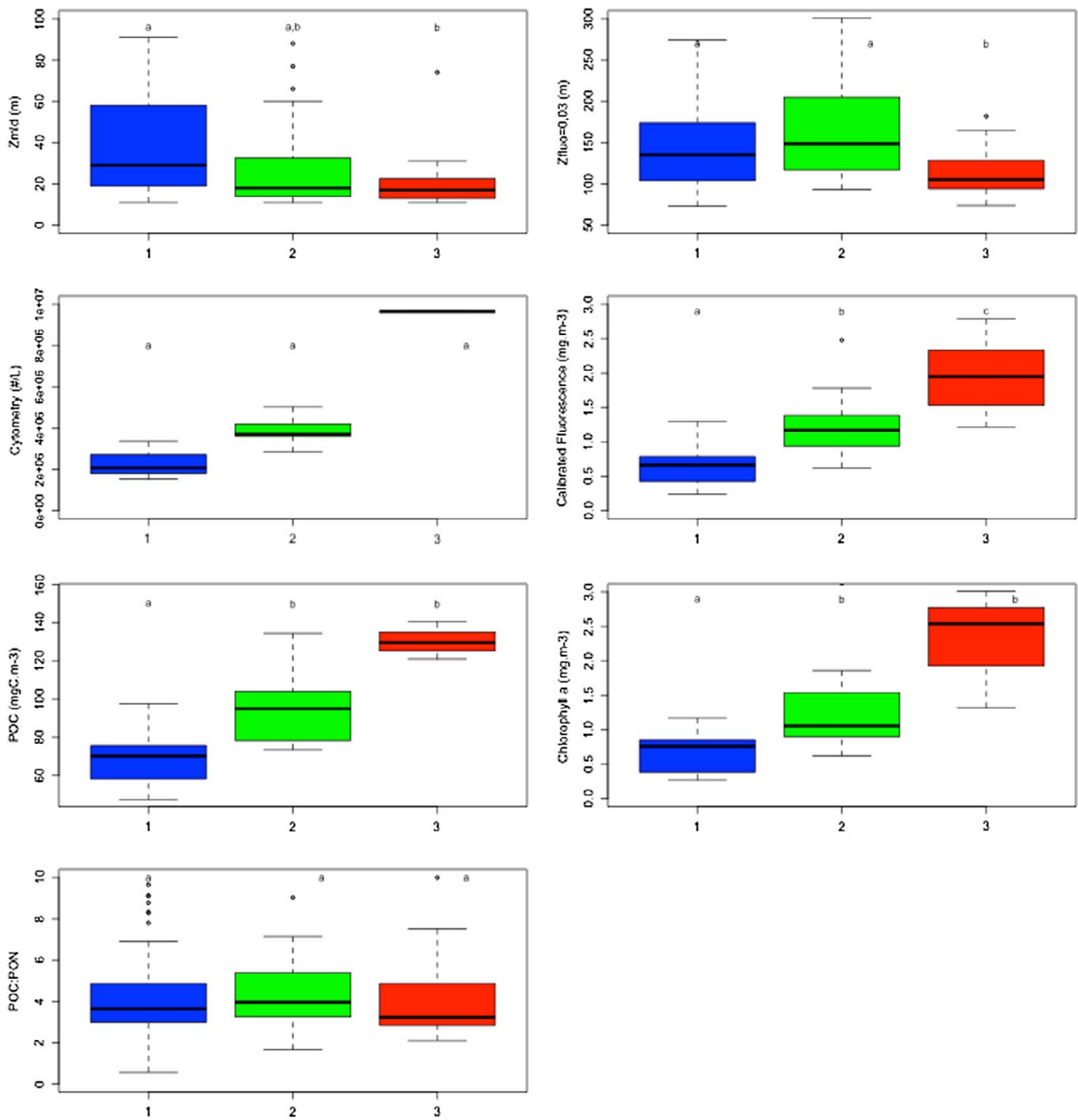

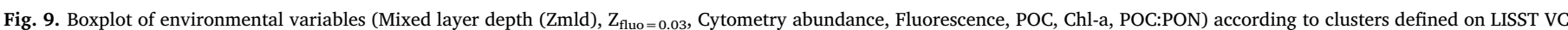

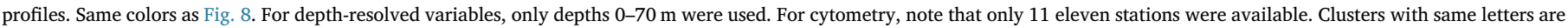
not significantly different from each other according to a Kruskal-Wallis test followed by a Nemenyi post-hoc test.

horizontal distribution of these three profile types, it is useful to consider the preceding winter period when deep convection was occurring over a large region centered on station 99 (See Donoso et al., 2017; Mayot et al., 2017 and Severin et al., 2017). This intense process created two well defined zones: the Deep Convection Zone (DCZ) with homogeneous vertical profiles, low phytoplankton and high nutrient concentrations, and the peripheral zone with various degrees of stratification and phytoplankton abundance. In spring, the horizontal circulation and turbulent restratification has only weakly modified the winter distribution. The DCZ stratified later than the peripheral zone, which led to a later but stronger phytoplankton bloom (Mayot et al., 2017).

The cluster with high VC (red) is present in the former convection region and shows surface maximum VC and Chl-a, typical of a recent bloom. The intermediate cluster (green) is spread in the peripheral region of the convection (Fig. $8 \mathrm{~b}$ and c). The low VC cluster (blue) is scattered North and South of the convection region, except East of Baleares, where there is a contiguous region of low VC. In the vertical, the VC profile shape generally resembles the fluorescence profile (see Fig. 2) except near the surface, probably due to non-photochemical quenching. When a deep Chl-a maximum was present, its depth corresponded to a local maximum of VC but weaker in amplitude, possibly indicating photoacclimation.

\subsection{Limits of our analysis}

The conditions of the cruise were favorable for use of the LISST to quantify the phytoplankton pool: open ocean waters, actively growing cells and high dominance of a few cell types approximately spherical in shape. Other datasets must be gathered to test whether our results can be easily replicated elsewhere.

In order to use LISST data, a background (clear water) scattering value has to be subtracted before the inversion step to estimate the particle volume. This background value is estimated by either clear water (usually $0.2 \mu \mathrm{m}$ filtered) on deck or in situ clear water. Here, as Barone et al. (2015), we chose to use the minimum of in situ scattering between 200 and $1000 \mathrm{~m}$ for each profile. Since this layer has low and rather constant POC $\left(10-50 \mathrm{mgC} \mathrm{m}^{-3}\right)$, we argue that it can be considered as a stable reference across stations, with the change of background being only due to fluctuations in the instrument's optics. Using a single background value applied to all the profiles led to a dataset with a larger variance across profiles and was therefore abandoned. The high VC and variability at classes 31 and $32(>180 \mu \mathrm{m})$ possibly contaminated classes smaller than $130 \mu \mathrm{m}$. The origin of these high values 
and variability may lie in the suboptimal vertical positioning of the LISST-Deep on the rosette. Although we cannot accurately estimate the extent of this contamination, observations in controlled laboratory experiments showed a significant contamination of VC as far as 8 classes away from the actual size class of particles present in the sample (leakage effect, Agrawal and Pottsmith, 2000). We observed that high VC values at classes 31 and 32 led to reduced VC for classes down to $30 \mu \mathrm{m}$. Therefore, the VC values for the $15-109 \mu \mathrm{m}$ particle pool may be underestimated. Mounting the LISST horizontally below the rosette and using a slower cable velocity, which would produce more data per meter, could probably minimize the noise observed in classes 31 and 32.

\section{Conclusion}

As demonstrated by the combination of laser diffraction (LISST), flow cytometry, and optical microscopy data, the 2013 spring bloom in the Gulf of Lions was characterized by a dominance of nanophytoplankton with mean size $5 \mu \mathrm{m}$, mostly represented by nanoflagellates and nanodiatoms (Minidiscus trioculatus). This nanophytoplankton dominance, observed by flow cytometry and identified by microscopy, was clearly distinguished in the LISST signal by a large peak between 2.1 and $10.8 \mu \mathrm{m}$. While cytometry and microscopy allows for the determination of bloom composition for a limited number of depths and stations, in situ deployment of LISST provides high-resolution, depthresolved distributions and sizes of key particle pools over an extended area thanks to its high sampling frequency. To further take advantage of these three techniques to characterize phytoplankton, dedicated laboratory experiments must be undertaken. As a perspective, since LISST is mostly restricted to the size class $<200 \mu \mathrm{m}$ (nano- and microplankton and particles), we believe it would be very promising to combine the LISST with the LOPC and the Underwater Vision Profiler in order to build a continuous particle size distribution covering picophytoplankton to zooplankton, along with identification of larger particles (Picheral et al., 2010). This will help to characterize ecosystem productivity, the transfer of energy to upper trophic levels (Espinasse et al., 2014) and vertical matter export from the surface to the deep ocean (Guidi et al., 2008).

\section{Acknowledgements}

We acknowledge sponsorship from WP2 MISTRALS-MERMEX program. This study is a contribution to the international SOLAS, IMBER and LOICZ program, supported by Pôle Mer Méditerranée. We thank Véronique Cornet-Barthaux for help with microscopy, Alain de Verneil for english proofreading, as well as the captain and crew of R/V Le Suroît. R Leroux was funded by MERMEX-IPP. All data used are available through http://mistrals.sedoo.fr/MERMeX/. The two reviewers are thanked for their constructive comments that helped improving the manuscript.

\section{References}

Agrawal, Y.C., Pottsmith, H.C., 2000. Instruments for particle size and settling velocity observations in sediment transport. Mar. Geol. 168 (1), 89-114.

Andrews, S.W., Nover, D.M., Reuter, J.E., Schladow, S.G., 2011. Limitations of laser diffraction for measuring fine particles in oligotrophic systems: pitfalls and potential solutions. Water Resour. Res. 47 (5).

Anglès, S., Jordi, A., Garcés, E., Masó, M., Basterretxea, G., 2008. High-resolution spatiotemporal distribution of a coastal phytoplankton bloom using laser in situ scattering and transmissometry (LISST). Harmful Algae 7 (6), 808-816.

Barone, B., Bidigare, R.R., Church, M.J., Karl, D.M., Letelier, R.M., White, A.E., 2015. Particle distributions and dynamics in the euphotic zone of the North Pacific Subtropical Gyre. J. Geophys. Res.: Oceans 120 (5), 3229-3247.

Caliński, T., Harabasz, J., 1974. A dendrite method for cluster analysis. Commun. Stat. Theor. Methods 3 (1), 1-27.

Claustre, H., Hooker, S., Van Heukelen, L., Berthon, J.-F., Barlow, R., Ras, J., Sessions, H., Targa, C. Thomas, C.S., Van Der Linde, D., Marty, J.C., 2004. An intercomparison of HPLC Phytoplankton pigment methods using in situ samples: application to remote sensing and database activities. Mar. Chem. 85, 41-61.

Conan, P., 2013. DEWEX-MERMEX 2013 LEG2 cruise. RV Le Suroît. http://dx.doi.org/10 $17600 / 13020030$.

De Boyer Montegut, C., Madec, G., Fischer, A.S., Lazar, A., Iudicone, D., 2004. Mixed layer depth over the global ocean: an examination of profile data and a profile-based climatology. J. Geophys. Res. - Oceans. http://dx.doi.org/10.1029/2004JC002378.

Donoso, K., Carlotti, F., Pagano, M., Hunt, B., Escribano, R., Berline, L., 2017. Zooplankton community response to the winter 2013 deep convection process in the NW Mediterranean Sea. J. Geophys. Res. Oceans. http://dx.doi.org/10.1002/ 2016JC012176.

Dugenne, M., Thyssen, M., Nerini, D., Mante, C., Poggiale, J.-C., Garcia, N., Garcia, F., Grégori, G.J., 2014. Consequence of a sudden wind event on the dynamics of a coastal phytoplankton community: an insight into specific population growth rates using a single cell high frequency approach. Front. Microbiol. 5, 485. http://dx.doi.org/10. 3389/fmicb.2014.004.

Durrieu de Madron et al., 2017. Deep sediment resuspension and thick nepheloid layer generation by open-ocean convection. J. Geophys. Res. - Oceans. http://dx.doi.org/ 10.1002/2016JC012062.

Espinasse, B., Carlotti, F., Zhou, M., Devenon, J.L., 2014. Defining zooplankton habitats in the Gulf of Lion (NW Mediterranean Sea) using size structure and environmental conditions. Mar. Ecol. Prog. Ser. 506, 31-46.

Font-Muñoz, J.S., Jordi, A., Anglès, S., Basterretxea, G., 2015. Estimation of phytoplankton size structure in coastal waters using simultaneous laser diffraction and fluorescence measurements. J. Plankton Research, fbv041.

Goldman, J.C., MacCarthy, J.J., Peavey, D.G., 1979. Growth rate influence on the chemical composition of phytoplankton in oceanic waters. Nature 279, 210-215.

Grégori, G., Colosimo, A., Denis, M., 2001. Phytoplankton group dynamics in the Bay of Marseilles during a 2-year survey based on analytical flow cytometry. Cytometry 44 (3), 247-256.

Guidi, L., Gorsky, G., Claustre, H., Miquel, J.-C., Picheral, M., Stemmann, L., 2008. Distribution and fluxes of aggregates $>100 \mathrm{mu} \mathrm{m}$ in the upper kilometer of the South-Eastern Pacific. Biogeosciences 5, 1361-1372.

Herman, A.W., Beanlands, B., Phillips, E.F., 2004. The next generation of optical plankton counter: the laser-OPC. J. Plankton Res. 26 (10), 1135-1145.

Karageorgis, A.P., Georgopoulos, D., Kanellopoulos, T.D., Mikkelsen, O.A., Pagou, K., Kontoyiannis, H., Kontoyianni, A., Anagnostou, C., 2012. Spatial and seasonal variability of particulate matter optical and size properties in the eastern mediterranean sea. J. Marine Syst. 105, 123-134.

Karp-Boss, L., Azevedo, L., Boss, E., 2007. LISST-100 measurements of phytoplankton size distribution: evaluation of the effects of cell shape. Limnol. Oceanogr. Methods 5, 396-406.

Kostadinov, T.S., Siegel, D.A., Maritorena, S., Guillocheau, N., 2012. Optical assessment of particle size and composition in the Santa Barbara Channel, California. Appl. Opt. 51 (16), 3171-3189.

Many, G., Bourrin, F., de Madron, X.D., Pairaud, I., Gangloff, A., Doxaran, D., et al., 2016 Particle assemblage characterization in the Rhone river ROFI. J. Mar. Syst. 157, 39-41.

Marie, D., Rigaut-Jalabert, F., Vaulot, D., 2014. An improved protocol for flow cytometry analysis of phytoplankton cultures and natural samples. Cytometry Part A 85 (11), 962-968.

Mayot, N., D'Ortenzio, F., Ribera d'Alcalà, M., Lavigne, H., Claustre, H., 2016. Interannual variability of the Mediterranean trophic regimes from ocean color satellites. Biogeosciences 13 (6), 1901-1917.

Mayot, N., D'Ortenzio, F., Taillandier, V., Prieur, L., Pasqueron de Fommervault, O., Claustre, H., Ellipsis, Conan, P., 2017. Physical and biogeochemical controls of the phytoplankton blooms in North-Western Mediterranean Sea: a multiplatform approach over a complete annual cycle (2012-2013 DEWEX experiment). J. Geophys. Res.: Oceans. http://dx.doi.org/10.1002/2016JC012052.

Menden-Deuer, S., Lessard, E.J., 2000. Carbon to volume relationships for dinoflagellates, diatoms, and other protest plankton. Limnol. Oceanogr. 45 (3), 569-579.

Mikkelsen, O.A., Milligan, T.G., Hill, P.S., Chant, R.J., Jago, C.F., Jones, S.E., et al., 2008. The influence of schlieren on in situ optical measurements used for particle characterization. Limnol. Oceanogr. Methods 6, 133-143.

Montagnes, D.J., Berges, J.A., Harrison, P.J., Taylor, F., 1994. Estimating carbon, nitrogen, protein, and chlorophyll a from volume in marine phytoplankton. Limnol. Oceanogr. 39 (5), 1044-1060.

Peters, R.H., 1983. The ecological implications of body size. Cambridge Studies in Ecology 1576 (2), 1-325.

Picheral, M., Guidi, L., Stemmann, L., Karl, D.M., Iddaoud, G., Gorsky, G., 2010. The Underwater Vision Profiler 5: an advanced instrument for high spatial resolution studies of particle size spectra and zooplankton. Limnol. Oceanogr.-Methods 8, $462-473$.

Pujo-Pay, M., Raimbault, P., 1994. Improvement of the wet-oxidation procedure for simultaneous determination of particulate organic nitrogen and phosphorus collected on filters. Mar. Ecol. Prog. Ser. 203-207.

Reynolds, A., Richards, G., de la Iglesia, B., Rayward-Smith, V., 1992. Clustering rules: a comparison of partitioning and hierarchical clustering algorithms. J. Math. Model. Algorithms 5, 475-504.

Rienecker, E., Ryan, J., Blum, M., Dietz, C., Coletti, L., Marin III, R., Bissett, W.P., 2008. Mapping phytoplankton in situ using a laser-scattering sensor. Limnol. Oceanogr. Methods 6, 153-161.

Schneider, C.A., Rasband, W.S., Eliceiri, K.W., 2012. NIH Image to ImageJ: 25 years of image analysis. Nat. Methods 9 (7), 671-675.

Schöniger, 1952. Über eine Modifikation der Mikrostickstoffbestimmung nach DumasPregl. Microchim. Acta 39 (3), 229-233.

Serra, T., Colomer, J., Cristina, X.P., Vila, X., Arellano, J.B., Casamitjana, X., 2001. 
Evaluation of laser in situ scattering instrument for measuring concentration of phytoplankton, purple sulfur bacteria, and suspended inorganic sediments in lakes. J. Environ. Eng. 127 (11), 1023-1030.

Severin, T., Kessouri, F., Rembauville, M., Sánchez-Pérez, E.D., Oriol, L., Caparros, J., Ellipsis \& Mayot, N., 2017. Open-ocean convection process: a driver of the winter nutrient supply and the spring phytoplankton distribution in the Northwestern Mediterranean Sea. J. Geophys. Res.: Oceans. http://dx.doi.org/10.1002/ 2016JC012664.

Strickland, J.D.H., 1965. Phytoplankton and marine primary production. Annu. Rev. Microbiol. 19, 127-162.

Throndsen, J., Hasle, G.R., Tangen, K., 2007. Phytoplankton of Norwegian Coastal Waters. Almater Vorlag As, Oslo, pp. 343p.

Thyssen, M., Gregori, G.J., Grisoni, J.-M., Pedrotti, M.-L., Mousseau, L., Denis, M.J., 2014. Onset of the spring bloom in the northwestern Mediterranean Sea: influence of environmental pulse events on the in situ hourly-scale dynamics of the phytoplankton community structure. Front. Microbiol. 5.
Vaulot, D., Chisholm, S.W., 1987. A simple model of the growth of phytoplankton populations in light/dark cycles. J. Plankton Res. 9 (2), 345-366.

Veldhuis, M.J., Kraay, G.W., 2000. Application of flow cytometry in marine phytoplankton research: current applications and future perspectives. Scientia Marina 64 (2), 121-134.

Vidussi, F., Claustre, H., Bustillos-Guzman, J., Cailliau, C., Marty, J.C., 1996. Determination of chlorophylls and carotenoids of marine phytoplankton: separation of chlorophyll a from divinyl-chlorophyll a and zeaxanthin from lutein. J. Plankton Res. 18, 2377-2382.

White, A.E., Letelier, R.M., Whitmire, A.L., Barone, B., Bidigare, R.R., Church, M.J., Karl, D.M., 2015. Phenology of particle size distributions and primary productivity in the North Pacific subtropical gyre (Station ALOHA). J. Geophys. Res.: Oceans 120 (11), 7381-7399.

Yentsch, C.M., Horan, P.K., Muirhead, K., Dortch, Q., Haugen, E., Legendre, L., et al., 1983. Flow cytometry and cell sorting: a technique for analysis and sorting of aquatic particles. Limnol. Oceanogr. 28 (6), 1275-1280. 